\title{
MULCH AND PLANTING DEPTH AFFECT LIVE OAK (QUERCUS VIRGINIANA MILL.) ESTABLISHMENT
}

\section{by Edward F. Gilman ${ }^{1}$ and Jason Grabosky ${ }^{2}$}

\begin{abstract}
This study was designed to evaluate the impact of several planting depths and mulch depth, particle size, and placement on tree establishment. Except for one period 2 weeks after transplanting, mulch depth and mulch particle size did not affect first-year stress (stem xylem potential) or growth of $76 \mathrm{~mm}$ (3 in.) caliper, balled-and-burlapped, transplanted live oak (Quercus virginiana Mill.). Negative effects of deep [15 mm (6 in.)] mulch 2 weeks after transplanting occurred for the mixed particle-sized material only. Mulch placed over the root ball intercepted water, causing a drier root ball and resulting in greater tree stress and reduced survival following light applications of water than for trees with no mulch over the root ball. This result did not occur following heavy applications of water. Keeping the ground near trees free of vegetation chemically had the same effect on post-planting stress and growth as mulching did. Soil over the root ball resulting from deep planting intercepted water, resulting in more tree stress and greater likelihood of tree death in the first 4 weeks after planting. However, trees planted deeply were less stressed 3 months after planting. No root ball settlement occurred in the first 6 months after planting container-grown trees.
\end{abstract}

Key Words. Backfill; bare soil; turfgrass; competition; mulching; depth; Quercus; settling; transplanting.

Applying mulch on and around the root ball of newly installed trees is standard practice in many locations (Watson and Himelick 1997). However, mulch usage is less common in drier locations such as the southwestern United States. Applying mulch around the base of the tree has been associated with increased growth compared to allowing turf to grow up close to the trunk of landscape trees (Watson 1988; Green and Watson 1989). Lacking any scientific data, clinical observations list the drawbacks to placing mulch against the trunk as increased vole damage, decayed bark, slow soil warming in spring, and girdling root formation (Johnson and Hauer 2000).

Although bark is currently used regularly as surface mulch in many regions, pine bark should not be incorporated into backfill soil around newly planted trees. For example, when aged pine bark was mixed 50:50 with backfill soil, induced nitrogen deficiency symptoms appeared on red maple (Acer rubrum L.), and shoot growth was reduced during the first year following planting (Smalley and Wood 1995). However, growth was improved when pine bark was mixed with backfill soil around newly planted azalea (Rhododendron spp.) (Beeson and Keller 1998).

Johnson and Hauer (2000) described tree health problems attributed to inappropriate planting depth. Arborists and other professionals continue to report that many trees are planted too deep and suffer as a result. However, there is only one published report in the scientific literature on the negative impact of planting depth on landscape tree performance (Broschat 1995), and it was performed on palm trees.

The objectives of this study were to (1) determine the influence of mulch particle size, depth, and placement on tree establishment, (2) determine the effect of planting depth on early tree establishment, (3) determine how irrigation or rainfall amount modifies the effects of mulch and planting depth, and (4) determine whether trees settle after planting.

\section{MATERIALS AND METHODS Mulch Study One}

Twenty-four acorn-propagated, $6.5 \mathrm{~cm}$ (2.5 in.) caliper, nursery-grown live oaks (Quercus virginiana Mill.) growing in a Millhopper fine sand (loamy, silicaceous, hyperthermic Grossarenic Paleudults) were transplanted into the same soil about $32 \mathrm{~m}(100 \mathrm{ft})$ away with a $71 \mathrm{~cm}$ (28 in) tree spade. Trees were not wrapped in burlap or a basket and were placed in a row on $2.4 \mathrm{~m}(8 \mathrm{ft})$ centers. Half the trees received an $8 \mathrm{~cm}$ ( 3 in.) deep layer of fresh pine bark mulch [5 to $8 \mathrm{~cm}$ ( 2 to $3 \mathrm{in}$.) particle size] up to the trunk in a 2.4 $\times 2.4 \mathrm{~m}(8 \times 8 \mathrm{ft})$ square area around each tree; half the trees received no mulch and the $2.4 \times 2.4 \mathrm{~m}(8 \times 8 \mathrm{ft})$ plots were kept bare. Two replicates of each treatment were placed in each of six blocks for a total of 2 replicates/treatment $\times 2$ treatments $\times 6$ blocks $=24$ trees. Glyphosate was sprayed periodically over all plots to keep weeds in check. That same volume of herbicide was used on mulched and bare plots, even though there were few weeds in the mulched plots. Herbicide was sprayed about four times each year during the 2 -year study. Irrigation was applied to the root ball regularly to keep all trees healthy. Trees were not pruned during the study.

A pressure bomb (Soil Moisture Inc., Santa Barbara, CA) was used to periodically evaluate stem xylem water potential (hereafter referred to as stress) after transplanting. The more negative the potential, the greater the stress inside the tree. This is a reliable method of evaluating stress after planting (Beeson and Gilman 1992). Stress in all trees was 
recorded at each measurement time. Trunk diameter increase measured $15 \mathrm{~cm}$ (6 in.) above the soil line was used to evaluate growth.

\section{Mulch Study Two}

Forty-nine $76 \mathrm{~mm}$ (3 in.) caliper, balled-and-burlapped Highrise $^{\mathrm{TM}}($ 'QVTIA' PP \#11,219) live oak were dug with a $80 \mathrm{~cm}$ (32 in.) diameter tree spade from a field nursery in sandy soil (Orlando fine sand) and placed in treated burlap and wire baskets in January 2002. Trees had been root pruned regularly during production. Trees were transported $64 \mathrm{~km}(40 \mathrm{mi})$ on a flatbed truck and planted on $3 \mathrm{~m}$ (16 ft) centers September 17, 2002, into the same soil as described in mulch study one. The site was a tree nursery with a uniform bahiagrass (Paspalum notatum 'Pensacola') cover for about 10 years prior to this test; therefore, the soil was not compacted [bulk density $1.49 \mathrm{~g} / \mathrm{cc}\left(0.86 \mathrm{oz} / \mathrm{in}^{3}\right)$ in the top $15 \mathrm{~cm}$ (6 in.)]. Holes were dug with a $1.3 \mathrm{~m}$ (50 in) diameter tree spade. Hole depth was adjusted so the point where the top-most root emerged from the trunk was positioned even with to about $2.5 \mathrm{~cm}$ (1 in.) above the surrounding landscape soil surface. The top tier of the wire basket was removed from each tree using wire cutters. No soil or mulch berm was constructed around the root balls. Trees were not pruned during the study.

The $4.8 \times 2.4 \mathrm{~m}(16 \times 8 \mathrm{ft})$ rectangular soil area around the root ball of each transplanted tree was managed by one of the following seven methods: (1) bare soil, (2) $8 \mathrm{~cm}$ (3 in.) deep chipped mulch [1.5 to $2.5 \mathrm{~cm}$ (0.75 to $1 \mathrm{in}$.) particle size], (3) $16 \mathrm{~cm}$ (6 in.) deep chipped mulch, (4) 8 $\mathrm{cm}$ (3 in.) deep shredded mulch [5 $\mathrm{mm}$ to $10 \mathrm{~cm}(0.13$ to 5 in.) particle size], (5) $16 \mathrm{~cm}$ (6 in.) deep shredded mulch, (6) $8 \mathrm{~cm}$ (3 in.) deep shredded mulch but no mulch on the root ball (the top of the root ball was not covered with mulch as it was in the other four mulch treatments), or (7) bahiagrass turf up to the edge of the root ball [sod was added around the root ball as needed so there was a uniform stand of bahiagrass across the entire $4.8 \times 2.4 \mathrm{~m}$ $(16 \times 8 \mathrm{ft})$ plot]. New sod was lightly watered by hand three times in the first 2 weeks to help establishment, but no water was applied to the top of the root ball. Mulch was derived from freshly chipped Taxodium distichum L. wood without bark. Seven trees received each of the seven surface treatments, for a total of 49 trees arranged in a randomized complete block design with one replicate from each treatment in each block. Each $4.8 \times 2.4 \mathrm{~m}(16 \times 8 \mathrm{ft})$ treatment area was surrounded by a healthy stand of bahiagrass that was mowed regularly. No fertilizer was added to the plots after planting, and the plot had not been fertilized for 6 years prior to this study.

Irrigation [56 L (15 gal)] was applied to the root ball for days 1 and 2 after transplanting, and $18 \mathrm{~L}$ (5 gal) was applied for days 3, 4, 6, and 8 using low-volume emitters to prevent runoff. Twenty-five liters (6.7 gal) irrigation was applied at each subsequent irrigation event unless we were conducting a stress test the following days. On these days, 6 mm (0.25 in.) was applied. A total of 578 L (153 gal) irrigation was applied to each tree through April 2003. Two hundred and fifty liters (66 gal) was applied to each tree May 14, 2003 (8 months after planting), because the weather had been very hot and dry, which is typical for this time of year, and some trees began dropping foliage. Irrigation was discontinued after May 14. Irrigation was applied only to the root ball not to soil beyond the root ball. Irrigation was applied uniformly over the entire $4.8 \times$ $2.4 \mathrm{~m}(16 \times 8 \mathrm{ft})$ rectangular plot area one time at 11 weeks after transplanting to simulate rainfall.

Beginning 20 days after transplanting, irrigation was withheld for several rainless days before xylem water potential was measured on one shoot on the south side of the middle of the canopy. A pressure bomb was used to evaluate xylem water potential. Stress on all 49 trees was recorded at each measurement time. Stress was measured one to several rainless days following rainfall events of 13 $\mathrm{mm}(0.5 \mathrm{in}$.) or more, and one or more rainless days following irrigation events of $6 \mathrm{~mm}$ (0.25 in.) or $48 \mathrm{~mm}$ (2 in.). We did this because we thought that perhaps the surface treatments would cause one tree response with heavy applications of water but a different response with light applications of water. Stress was measured on 9/20, 9/23, 9/29, 9/30, 10/5, 10/6, 10/20, 10/29, 11/4, 11/8, $11 / 21,11 / 22,11 / 27$, and $12 / 2(2002)$ and $2 / 3,3 / 26,4 / 18$, 4/24, 4/25, and 5/14 (2003).

\section{Planting Depth Study}

Forty-eight acorn-propagated, 5 to $7 \mathrm{~cm}$ (2 to 2.5 in.) caliper live oak in \#25 smooth-sided black plastic containers were planted into the same field soil as described above June 1014, 2003, on $0.3 \mathrm{~m}$ (10 ft.) centers. Holes were hand dug with straight sides and flat bottoms 10 to $15 \mathrm{~cm}$ (4 to $6 \mathrm{in}$.) wider than the root balls and adjusted to the appropriate depth described below. The same person packed the soil on the bottom of each hole by stepping into the hole and bouncing up and down several times all around the bottom of the hole. Root ball sides were sliced with a hand pruner top to bottom in 4 places about $2.5 \mathrm{~cm}$ ( 1 in.) deep into media. All circling roots on top of root ball were cut about $2.5 \mathrm{~cm}$ ( $1 \mathrm{in}$.) into media. After the root ball was placed in the hole at the correct depth a $15 \mathrm{~cm}$ (6 in.) wide volume of soil at the edge of the hole was loosened and pushed into the hole. The rest of the hole was filled with soil that came out of the hole. Water was added to settle backfill soil and soil was packed firmly with a person's foot. No berm or water ring was constructed around the root balls.

Twelve trees were installed at each of four planting depths with the point where the topmost root emerged 
from the trunk (referred to as the root flare) either $5 \mathrm{~cm}$ (2 in.) above grade, or $2.5 \mathrm{~cm}$ (1 in.), $10 \mathrm{~cm}$ (4 in.) or $18 \mathrm{~cm}$ (7 in.) below grade in a randomized complete block design with one replicate of each planting depth in each block. Hardwood mulch chips $8 \mathrm{~cm}$ ( 3 in.) deep were added over the root ball and around the tree in a $2.4 \times 3 \mathrm{~m}(8 \times 10 \mathrm{ft})$ rectangular area and kept weed-free with periodic glyphosate application.

Half the trees in each planting depth treatment were irrigated regularly to maintain vitality (frequent irrigation) and half were irrigated frequently enough to keep them from dying (survival irrigation), as defined in Beeson and Gilman (1992). Frequent irrigation comprised the following: 18 L (5 gal) three times weekly for 2 weeks then $3.8 \mathrm{~L}$ ( 1 gal) every other day through March 2004 [total 227 L (160 gal) irrigation applied]; survival irrigation was $18 \mathrm{~L}$ (5 gal) three times weekly for 2 weeks, $18 \mathrm{~L}$ ( 5 gal) on $7 / 11$, rainfall of 2.5 $\mathrm{cm}(1 \mathrm{in}$.) on $7 / 14,18 \mathrm{~L}$ ( 5 gal) on $7 / 18$, then no irrigation [total $151 \mathrm{~L}$ (40 gal) irrigation applied]. Periodic summer showers typical of the climate had begun about the time trees were planted. A small amount of irrigation was occasionally applied to the 24 trees in the frequent irrigation plots just prior to stress measurements as described below. There were a total of 48 trees in the study ( 4 planting depths $\times 2$ irrigation treatments $\times 6$ blocks).

A pressure bomb as described above was used to measure water stress 4,7 , and 11 weeks after planting. Typically, irrigation was withheld during a dry weather period, and water stress was measured on all trees beginning 2 or 3 days after withholding water until xylem potential at mid-day on several trees was less than $-2 \mathrm{MPa}$. This was a level associated with reduced photosynthesis in live oak (Beeson and Gilman 1992). The 24 frequently irrigated trees then received $6 \mathrm{~mm}$ (0.25 in.) irrigation over the root ball immediately following the stress measurement. This application was designed to simulate a light rainfall event. The next day, water stress on all 48 trees was measured beginning at noon. Measurement of all trees took about 90 minutes, and trees were irrigated with $50 \mathrm{~mm}$ (2 in.) at the end of the day.

Two stakes were driven into the soil just beyond the edge of the planting hole directly opposite one another so they lined up with the trunk. The tops of the stakes were about 8 $\mathrm{cm}$ (3 in.) above the top of the mulch. A string was tightened between the two stakes at planting and the trunk was marked where the string touched the trunk. Four months later (October 2003), the string was again stretched between the two stakes to determine whether the trees had settled. Trunk diameter $15 \mathrm{~cm}$ (6 in.) from the top of the mulch was measured at planting and 7 months later, in December 2003.

Regression and analysis of variance were used to analyze data using SAS. $P<0.01$ was considered statistically significant except where indicted otherwise.

\section{RESULTS AND DISCUSSION Mulch Study One}

Stem xylem potential in mulched and nonmulched plots was similar, and trunk diameter growth the 2 years following planting was similar for trees in both. Because there was no difference in performance between mulched and nonmulched plots, we wondered whether the increased growth on trees in the mulched landscape compared to trees with turf up to the trunk observed by Green and Watson (1989) was a mulch effect or simply the lack of turfgrass near the trunk. Mulch study two helped to answer this question.

\section{Mulch Study Two}

Two weeks after transplanting, trees were not irrigated for three consecutive sunny days until they were close to dying, based on Beeson and Gilman (1992). At the end of the third day, trees were irrigated over the root ball with $6 \mathrm{~mm}(0.25$ in.) water; 2 days later, $23 \mathrm{~mm}$ (0.9 in.) rain fell; then 2 days, later $6 \mathrm{~mm}$ (0.25 in.) irrigation was applied. Stress early in the afternoon the following day was significantly greater (more negative xylem potential) for trees in the 15 $\mathrm{cm}$ (6 in.) deep shredded mulch plots than in the $7.5 \mathrm{~cm}(3$ in.) deep shredded mulched plots, turf, or bare plots (Table 1). For all other measurement dates, neither mulch depth nor mulch particle size affected plant measurements during the first year after transplanting (data not shown).

Xylem potential measurements the following day [2 days after $6 \mathrm{~mm}$ (0.25 in.) irrigation] showed that trees with

Table 1. Xylem water potential 13:30 to $14: 30$ hours 3 weeks and 7 and 8 months following transplanting 76 $\mathrm{mm}$ ( 3 in). caliper Highrise ${ }^{\mathrm{TM}}$ live oak into plots with seven different surface treatments.

\begin{tabular}{llll}
\hline & \multicolumn{3}{c}{ Xylem potential (MPa) } \\
\cline { 2 - 4 } Surface treatment & 3 weeks & 7 months & 8 months \\
\hline $\begin{array}{l}\text { Shredded mulch } \\
\text { [150 mm (6 in.)] }\end{array}$ & $2.15 \mathrm{a}^{*}$ & $1.93 \mathrm{~b}$ & $2.00 \mathrm{~b}$ \\
Chipped mulch & $1.83 \mathrm{ab}$ & $1.80 \mathrm{~b}$ & $1.96 \mathrm{~b}$ \\
{$[150 \mathrm{~mm}$ (6 in.)] } & & & \\
Chipped mulch & $1.82 \mathrm{ab}$ & $1.86 \mathrm{~b}$ & $1.97 \mathrm{~b}$ \\
[75 mm (3 in.)] & & & \\
Bare ground/no mulch & $1.77 \mathrm{ab}$ & $2.02 \mathrm{~b}$ & $2.19 \mathrm{~b}$ \\
$\begin{array}{l}\text { Shredded mulch } \\
\text { [75 mm (3 in.)] }\end{array}$ & $1.63 \mathrm{~b}$ & $1.93 \mathrm{~b}$ & $1.95 \mathrm{~b}$ \\
$\begin{array}{l}\text { Turf/no mulch } \\
\text { Shredded mulch } \\
\text { [75 mm (3 in.)] but no } \\
\text { mulch on root ball }\end{array}$ & $1.54 \mathrm{~b}$ & $2.30 \mathrm{a}$ & $2.69 \mathrm{a}$ \\
\hline
\end{tabular}

* Means (calculated on seven trees per treatment) in a column followed by the same letter are not significantly different from each other at the $P<$ 0.05 level. 
mulch over the root ball were significantly more stressed than trees in the three treatments with no mulch on the root ball (Figure 1, top). The stress levels in the mulched trees were high enough to result in reduced photosynthesis and would have led to death in a day or two if irrigation was not applied at the end of the day (Beeson and Gilman 1992). Apparently, more water was able to enter the root ball to rehydrate the root system when no mulch was present over the ball.

Trees were then irrigated with $5 \mathrm{~cm}(2 \mathrm{in}$.) of water at the end of the day. Stress measurements the following day were identical for all treatments (data not shown). Apparently, $5 \mathrm{~cm}$ ( 2 in.) of water was enough to rehydrate the tree, but $6 \mathrm{~mm}$ (0.25 in.) was not when the root ball was mulched. This fin ding indicated that mulch could intercept some of the water from a light rainfall or light irrigation soon after planting, which can cause an increase in stress and result in tree death. The trees with mulch over the root ball would have been the first to die if we did not irrigate the following day.

Four weeks after transplanting, the weather again was dry for several days and trees became stressed close to the point of death. Heavy $[5 \mathrm{~cm}$ (2 in.)] irrigation was applied at the end of this dry period and xylem potential measured the following day. There were no differences among trees growing in the various surface treatments (Figure 1, bottom). There were no differences in xylem potential among treatments beyond 4 weeks after planting, whether they followed $6 \mathrm{~mm}(0.25$ in.) or $5 \mathrm{~cm}$ (2 in.) irrigation (data not shown) until spring, 7 months after planting. At 7 months after transplanting (late April), following 2 weeks without rain or irrigation, trees with turfgrass around the root ball were more stressed than all other surface treatments (Table 1). Early May was also dry, and we found that after 2 weeks without rain or irrigation (May 1 through May 14), trees in turfgrass plots were again more stressed than all others (Table 1).

Apparently, roots on trees in all treatments except turf had grown into landscape soil to a point where they could absorb enough water to maintain hydration regardless of mulch presence over the root ball. The potential problem with mulch over the ball appears to last only a few weeks after transplanting in Florida, where root systems grow

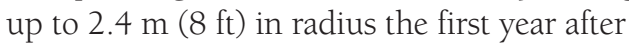
transplanting, resulting in a $6 \mathrm{~m}(20 \mathrm{ft})$ diameter root system (Gilman, unpublished). This negative effect of mulch over the root ball could last longer in cooler climates where root growth is much slower (Watson and Himelick 1997). Once roots had grown substantially into the landscape soil, the trees were able to maintain hydration regardless of surface treatment. Differences among treatments after 4 weeks following transplanting may be subdued because of low transpiration and water demand during winter months. Perhaps differences would have lasted longer if trees were planted during the normally hot, dry spring season in Florida.

One tree died and another one lost all its leaves and came close to dying in the normally hot, dry weather in May 2003, 8 months after transplanting. Both trees were in the turf surface treatment plots. Caliper growth in the year after
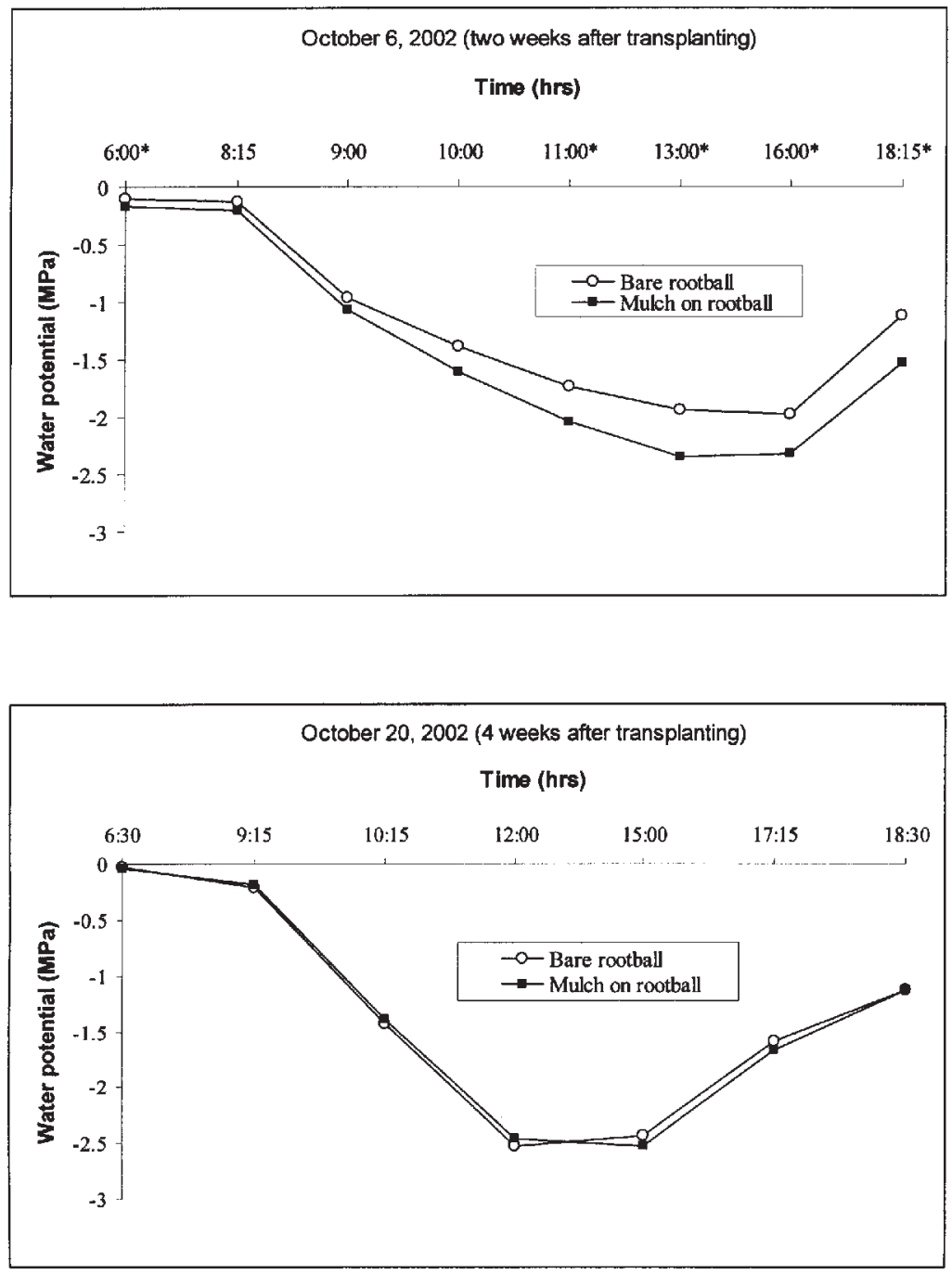

Figure 1. Xylem potential the day following $6 \mathrm{~mm}(0.25 \mathrm{in}$.) irrigation at the end of the first dry weather period 2 weeks after transplanting (top) and following $50 \mathrm{~mm}$ ( 2 in.) irrigation at the end of the second dry weather period 4 weeks after transplanting for treatments with mulch over the root ball and treatments with no mulch on the root ball. Asterisk $\left({ }^{*}\right)$ indicates significant difference between mulch treatments. 
Table 2. Trunk caliper growth in the first 12 months after transplanting $76 \mathrm{~mm}$ ( 3 in.) caliper Highrise ${ }^{\mathrm{TM}}$ live oak into plots with seven different surface treatments.

\begin{tabular}{ll}
\hline Surface treatment & $\begin{array}{l}\text { Caliper growth in the } 12 \text { months } \\
\text { after transplanting mm (in.) }\end{array}$ \\
\hline Shredded mulch [75 mm (3 in.)] & $17(0.65) \mathrm{a}^{*}$ \\
Shredded mulch [150 mm (6 in.)] & $16(0.63) \mathrm{a}$ \\
Chipped mulch [75 mm (3 in.)] & $15(0.61) \mathrm{a}$ \\
Chipped mulch [150 mm (6 in.)] & $15(0.59) \mathrm{ab}$ \\
Bare ground/no mulch on root ball & $14(0.55) \mathrm{ab}$ \\
Shredded mulch [75 mm (3 in.)]/ & $12(0.46) \mathrm{b}$ \\
no mulch on root ball & $7(0.27) \mathrm{c}$ \\
\hline Turfgrass/no mulch on root ball &
\end{tabular}

* Means (calculated on seven trees per treatment) followed by the same letter are not significantly different from each other at the $P<0.05$ level

transplanting was also significantly less in the turf surface treatment plots than in trees in four of the five mulched plots (Table 2), indicating stressed trees. The established roots of the bahiagrass turf probably slowed growth of tree roots out from the root ball (Whitcomb 1981) and retarded establishment. Watson (1988) also showed reduced tree growth when turf was allowed to grow up close to the trunk compared to mulched trees. Our data from both studies showed that trees maintained with bare soil were no more stressed than trees in the mulched plots. Therefore, Watson's findings in 1988 that increased growth on mulched trees compared to trees with turfgrass close to the trunk may have been a result of lack of turf, not the presence of mulch.

\section{Planting Depth Study}

Planting depth did not influence tree water stress during the first dry period 4 weeks after planting (Figure 2, top, survival irrigation line). However, water stress increased $(P<0.01)$ with planting depth the day after $6 \mathrm{~mm}$ (0.25 in.) irrigation was added following this first dry period (Figure 2, top, frequent irrigation line). This finding indicated that water from this light irrigation had difficulty reaching the root ball and rehydrating the tree as planting depth increased. Trees planted with the point where the topmost root met the trunk close to the surface were able to use the small amount of water added [6 $\mathrm{mm}(0.25 \mathrm{in}$.)] because it was able to seep into the root ball from above. The soil and mulch over the root ball on deep-planted trees apparently intercepted and retained water, making it unavailable to tree roots in the ball. Frequently irrigated trees received $2.5 \mathrm{~cm}(1 \mathrm{in}$.) at the end of the day. Water stress the following day was similar for all planting depths (data not shown), indicating that adding 2.5 $\mathrm{cm}$ (1 in.) irrigation resulted in wetting all root balls equally. Soil over the root ball appears to have no impact on water stress when $2.5 \mathrm{~cm}$ ( 1 in.) water is added.

There was no difference in stress among planting depths 7 weeks after planting following the second dry-down
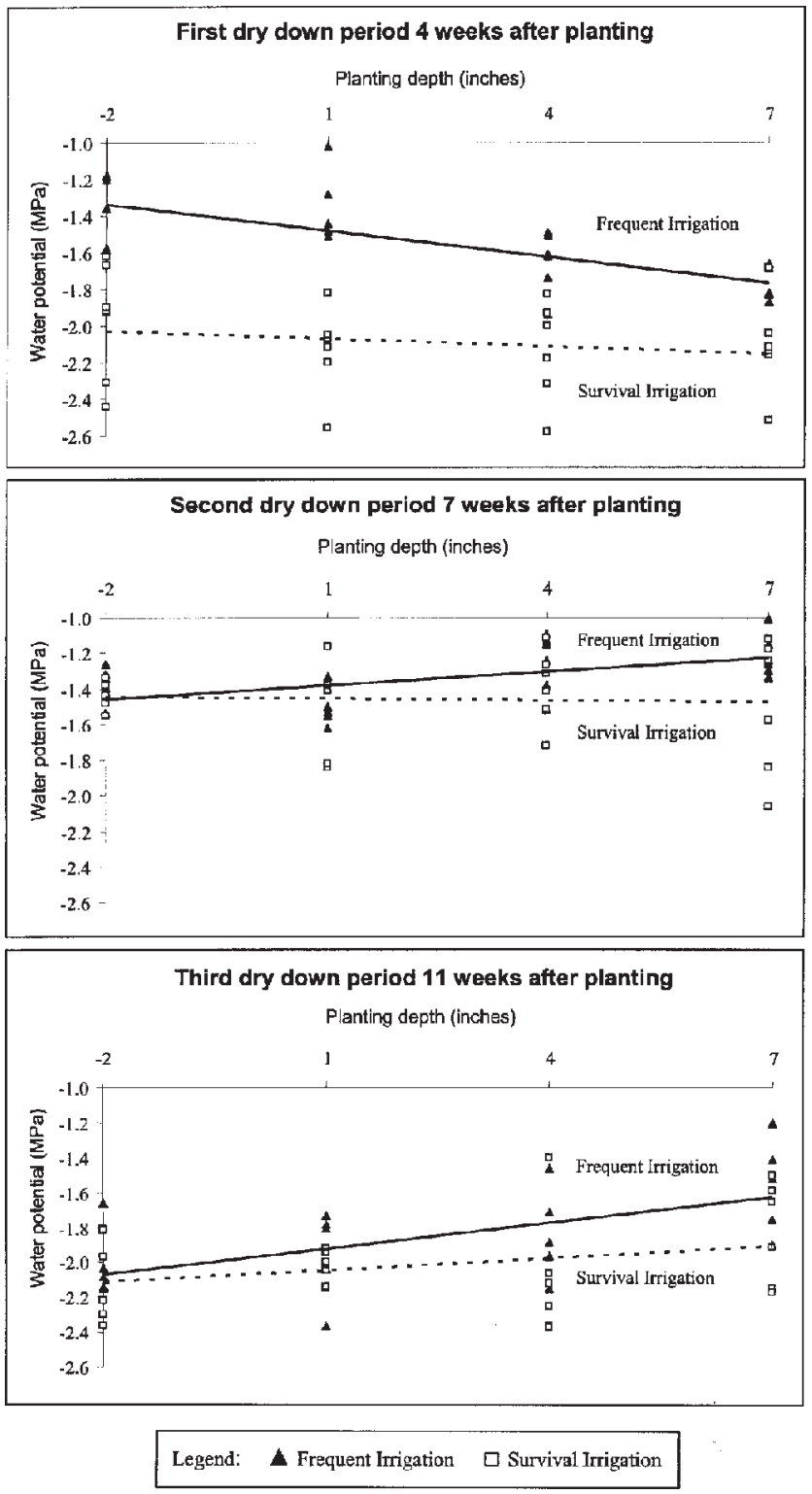

Figure 2. Stem xylem potential the day following $6 \mathrm{~mm}$ (0.25 in.) irrigation (frequent irrigation line) or no irrigation (survival irrigation line) 4, 7, and 11 weeks after planting 50 to $63 \mathrm{~mm}$ ( 2 to $2.5 \mathrm{in}$.) caliper live oak following an extended period of dry weather.

period (Figure 2, middle). However, 11 weeks after planting (the third dry-down period), the deepest planted trees were significantly less stressed $(P<0.01)$ than shallow-planted trees the day after $6 \mathrm{~mm}$ (0.25 in.) irrigation was applied (Figure 2, bottom, frequent irrigation line). There was no effect of planting depth on trees not irrigated the day before stress measurement (Figure 2, bottom, survival irrigation line). This finding might indicate that roots were growing in backfill soil that was placed over 
the root ball on the deep-planted trees. Trees planted with no soil over the root ball could not produce roots there. Longer-term studies with these 48 trees will determine whether roots will grow up toward the surface from the top of the root ball and whether these can be a source of stemgirdling roots as suggested by Johnson and Hauer (2000).

No settlement of the root balls occurred in the first 4 months after planting (data not shown). Survival of live oak $5 \mathrm{~cm}$ (2 in.) in caliper was 100\% with just $151 \mathrm{~L}$ (40 gal) irrigation applied in the 5 weeks after planting at the beginning of the rainy season. Planting depth did not impact trunk diameter growth the first 7 months after planting.

In summary, except once 2 weeks after planting, mulch depth and mulch particle size did not affect stress or growth in the first year after transplanting. Mulch placed over the root ball appeared to intercept water, which resulted in greater tree stress and reduced survival following light applications of water in the months after transplanting compared to trees with no mulch over the root ball. Increased growth rate for mulched trees following transplanting appears to be caused by lack of turf, not the presence of mulch. In other words, keeping the ground free of vegetation had the same effect on survival and growth as mulching the first year after planting. Eliminating turf around transplanted trees by mulching or by maintaining the ground bare of all vegetation reduced stress and can increase survival in sandy soil compared to allowing turf to grow close to the trunk.

Soil placed over the root ball at planting can intercept water, resulting in more tree stress in the weeks immediately following planting live oak into sandy soil. However, this same soil may increase the soil volume available for root growth, resulting in less stress in dry weather 11 weeks after planting. No root ball settlement occurred in the first 4 months after planting.

\section{LITERATURE CITED}

Beeson, R.C., Jr., and E.F. Gilman. 1992. Water stress and osmotic adjustment during post-digging acclimatization of Quercus virginiana produced in fabric containers. J. Environ. Hortic. 10:208-214.

Beeson, R.C., Jr., and K.G. Keller. 1998. Yard waste compost as a landscape soil amendment for azaleas. J. Environ. Hortic. 19:222-225.
Broschat, T. 1995. Planting depth affects root growth and nutrient content on transplanted pygmy date palms. HortScience 30:1031-1032.

Green, T.L., and G.W. Watson. 1989. Effects of turfgrass and mulch on the establishment and growth of bareroot sugar maples. J. Arboric. 15:268-272.

Johnson, G., and R. Hauer. 2000. A Practitioner's guide to Stem Girdling Roots of Trees. www.extension.umn.edu/ distribution/naturalresources/DD7501.html (accessed 7/30/04).

Smalley, T.J., and C.B. Wood. 1995. Effect of backfill amendment on growth of red maple. J. Arboric. 21:247-249

Watson, G.W. 1988. Organic mulch and grass competition influence tree root development. J. Arboric. 14:200-203.

Watson, G.W., and E.B. Himelick. 1997. Principles and Practice of Planting Trees and Shrubs. International Society of Arboriculture, Champaign, IL. 200 pp.

Whitcomb, C.E. 1981. Response of woody landscape plants to bermudagrass competition and fertility. J. Arboric. 7:191-194.

Acknowledgments. Thanks to the Great Southern Tree Conference (www.GreatSouthernTreeConference.org) and the Florida Nurserymen and Growers Association for partial funding of this research. Florida Agricultural Experiment Station Publication No. R-10108.

\author{
${ }^{1 *}$ Professor \\ Department of Environmental Horticulture \\ University of Florida \\ Gainesville, FL 32611, U.S. \\ ${ }^{2}$ Assistant Professor \\ Ecology, Evolution and Natural Resources \\ Rutgers University \\ New Brunswick, NJ, U.S. \\ *Corresponding author.
}


Résumé. Cette étude a été conçue pour évaluer l'impact de plusieurs profondeurs différentes de plantation, d'épaisseurs de paillis, de grosseurs et de disposition des particules de paillis, et ce en regard du degré de reprise de l'arbre. À l'exception d'une période de deux semaines après la plantation, l'épaisseur de paillis et la grosseur des particules de paillis n'influençaient en rien le stress de première année (potentiel du xylème de la tige) ou la croissance dans le cas de chênes verts de $76 \mathrm{~mm}$ de grosseur (Quercus virginiana) transplantés en mottes. Les effets négatifs d'un paillis épais $(15 \mathrm{~cm})$ n'apparaissaient deux semaines après la transplantation que dans le cas d'un paillis fait de particules mixtes en dimensions. Le paillis placé au-dessus de la motte de l'arbre interceptait l'eau, ce qui causait un assèchement de la motte et donc un plus grand stress sur l'arbre ainsi qu'un taux de survie réduit suite à des applications légères d'eau, et ce comparativement à des arbres sans paillis au-dessus de la motte de racines. Ceci ne se produisait par contre pas lors d'applications importantes d'eau. Garder le parterre à proximité de l'arbre libre de toute végétation au moyen de produits chimiques avait le même effet sur le stress postplantation et la croissance que dans le cas du paillis. Le sol au-dessus de la motte de racines, suite à une plantation en profondeur, interceptait l'eau, ce qui résultait en des arbres plus stressés et des taux de mortalité plus élevés dans les quatre premières semaines suivant la plantation. Quoiqu'il en soit, les arbres plantés en profondeur étaient moins stressés trois mois après la plantation. Aucune conclusion n'a pu être dégagée dans les six premiers mois suivants la plantation dans le cas d'arbres cultivés en contenant.

Zusammenfassung. Diese Studie zielt darauf ab, die Wirkungen von verschiedenen Pflanztiefen, Mulchtiefe, Korngröße und Platzierung auf die Standortetablierung haben. Mit Ausnahme einer Periode wurde das Wachstum von jungen Lebenseichen mit 76 mm Umfang 2 Wochen nach der Transplantation nicht durch die Teilchengröße und die Mulchtiefe beeinflusst. Die negativen Effekte der Mulchtiefe $(15 \mathrm{~mm})$ tauchte 2 Wochen nach der Verpflanzung nur bei gemischten Partikelgrößen auf. Über den
Wurzelballen platzierter Mulch beeinflusste die Wasserleitung, was zu trocknen Wurzelballen, größerem Baumstress, reduziertem Überleben nach leichter Wasserapplikation führte. Das trat nicht bei größeren Wassergaben auf. Mulchen hatte einen ähnlichen Effekt auf den Stress und das Wachstum wie die chemische Unkrautbekämpfung auf der Pflanzscheibe. Boden über dem Wurzelballen als Ergebnis tiefer Pflanzung führte zu Wasserstress und möglicherweise zu früherem Absterben in der ersten Zeit nach der Pflanzung. Dennoch waren tiefer gepflanzte Bäume nach drei Monaten weniger gestresst. In den ersten 6 Monaten nach der Pflanzung tauchte bei den Containerpflanzen keine Wurzelballsetzung auf.

Resumen. Este estudio fue diseñado para evaluar el impacto de varias profundidades de plantación y de mulching, tamaño de partículas y su localización en el árbol. Excepto para un período de 2 semanas después del trasplante, el espesor de la capa del mulch y el tamaño de las partículas de mulch no afectó el estrés del primer año (potencial del xilema del tronco) o el crecimiento de $76 \mathrm{~mm}$ (3 pulg) de calibre de encinos B\&B trasplantados (Quercus virginiana Mill.). Los efectos negativos de la capa de mulch [15 mm (6 pulg)] 2 semanas después del trasplante solamente ocurrieron para el material de tamaño mixto de partículas. El mulch colocado sobre la bola de raíces interceptó el agua causando una bola de raíces más seca y resultando en mayor estrés del árbol y reducida sobre vivencia después de aplicaciones ligeras de agua, que en árboles sin mulch sobre la bola. Esto no ocurrió después de aplicaciones pesadas de agua. Manteniendo químicamente libre de vegetación el terreno cerca de los árboles, dio el mismo efecto que el mulching sobre el estrés posttrasplante y el crecimiento. El suelo sobre la bola de raíces resultante de mantener el agua interceptada dio mayor estrés y mayor posibilidad de muerte en las primeras cuatro semanas después de la plantación. Sin embargo, los árboles plantados profundamente estuvieron menos estresados tres meses después de la plantación. No hubo asentamiento de la bola en los 6 meses después de la plantación de los árboles que crecieron en contenedor. 